\title{
Taller teórico y práctico de antropología forense
}

\section{Tania Delabarde}

\section{(2) OpenEdition Journals}

Edición electrónica

URL: http://journals.openedition.org/bifea/4000

DOI: $10.4000 /$ bifea.4000

ISSN: 2076-5827

\section{Editor}

Institut Français d'Études Andines

\section{Edición impresa}

Fecha de publicación: 1 agosto 2007

Paginación: 309

ISSN: 0303-7495

\section{Referencia electrónica}

Tania Delabarde, "Taller teórico y práctico de antropología forense », Bulletin de l'Institut français d'études andines [En línea], 36 (2) | 2007, Publicado el 01 febrero 2008, consultado el 01 diciembre 2020. URL : http://journals.openedition.org/bifea/4000 ; DOI : https://doi.org/10.4000/bifea.4000

\section{c) (i) $\Theta$}

Les contenus du Bulletin de l'Institut français d'études andines sont mis à disposition selon les termes de la licence Creative Commons Attribution - Pas d'Utilisation Commerciale - Pas de Modification 4.0 International. 


\section{Eventos}

\section{TALLER TEÓRICO Y PRÁCTICO DE ANTROPOLOGÍA FORENSE}

Quito, Ecuador, 19-23 de marzo de 2007

En el marco de la cooperación entre la Embajada de Francia en Quito y la Policía del Ecuador y siguiendo un pedido especial de la misma, se brindaron dos talleres teóricos y prácticos de antropología forense bajo la responsabilidad de Tania Delabarde, antropóloga e investigadora del IFEA en Ecuador. La antropología forense utiliza las metodologías de la arqueología y de la antropología física para la recuperación y el análisis de cuerpos descompuestos y/o esqueletizados de interés forense. El aporte de la antropología física en los casos forenses y la ausencia de especialistas en el país, motivaron el pedido y la realización de este taller para los diferentes actores de la justicia (jueces y fiscales) y de la policía (peritos de criminalística y médicos forenses). Durante 25 horas de cursos teóricos y prácticos, los participantes tuvieron los conocimientos básicos de antropología forense especificados en el programa siguiente:

- Antropología Forense: concepto, revisión histórica y estado actual

- Antropología Forense: de la escena inicial hasta la morgue

- recuperación de las evidencias en el sitio

- el protocolo de análisis en la morgue

- Introducción a la Osteología Humana

- terminología anatómica

- estructura del hueso

- el esqueleto axial (cráneo, columna vertebral, costillas)

- Osteología Humana

- el esqueleto apendicular (miembros superiores y inferiores, cintura pélvica)

- Introducción a la Odontología forense

- Perfil biológico

- determinación del sexo, edad, estatura y afinidades biológicas

- datos biológicos para la identificación

- Estimación del tiempo desde la muerte

- Determinación de las lesiones en el tejido óseo

- traumatismos contundentes

- traumatismos por armas blancas

- traumatismos por armas de fuego

- traumatismos por explosivos

Los talleres se realizaron en el Instituto de Medicina Legal en Quito y en los laboratorios de Criminalística en Guayaquil del 26 al 28 de marzo. 